\title{
Quality characteristics and antioxidant activity of bitter melon (Momordica charantia L.) dried by different methods
}

\author{
Kwang-Sup Youn ${ }^{1,2}$, Eun-Hye Park ${ }^{3}$, Kyung Young Yoon ${ }^{4 *}$ \\ ${ }^{1}$ Department of Food Science and Technology, Catholic University of Daegu, Gyeongsan 38430, Korea \\ ${ }^{2}$ Institute of Food Science and Technology, Catholic University of Daegu, Gyeongsan 38430, Korea \\ ${ }^{3}$ Department of Nutrition Management, Graduate School of Environment and Public Health Studies, Yeungnam University, \\ Daegu 42415, Korea \\ ${ }^{4}$ Department of Food and Nutrition, Yeungnam University, Gyeongsan 38541, Korea
}

\section{건조방법에 따른 여주의 품질특성 및 항산화 활성}

\author{
윤광섭 ${ }^{1.2} \cdot$ 박은혜 ${ }^{3} \cdot$ 윤경영 $4 *$ \\ ${ }^{1}$ 대구가톨릭대학교 식품공학전공, ${ }^{2}$ 대구가톨릭대학교 식품과학연구소, \\ ${ }^{3}$ 영남대 환경보건대학원 영양관리학과, ${ }^{4}$ 영남대학교 식품영양학과
}

\begin{abstract}
Bitter melon has many nutrients and is excellent for many physiological functions. Here, bitter melon was dried by various methods (sun drying, hot air drying, freeze drying, and infrared drying), and the quality characteristics and antioxidant activity of the dried bitter melon were determined to improve the utilization of bitter melon as a food. The freeze-dried bitter melon had the highest soluble solid content (1.27 ${ }^{\circ}$ Brix), and reducing sugar content of dried bitter melon was $220.33-247.13 \mathrm{mg} / 100 \mathrm{~g}$. The $\mathrm{pH}$ and acidity of the dried bitter melons were 4.38-4.79 and $0.60-0.69 \%$, respectively. The total amino acid content of the freeze-dried bitter melon was the highest, and the content of arginine, which has a bitter taste, was the highest in all the samples. Hot air-dried bitter melon had the highest polyphenol content, while the flavonoid content was the highest in infrared-dried bitter melon. However, there was no significant difference between the different drying methods. Antioxidant activity was significantly higher in hot air drying and infrared drying than in the other drying methods. Thus, freeze-dried bitter melon had superior physicochemical characteristics while infrared-dried and hot air-dried bitter melon had high antioxidant activity. Therefore, a proper drying method can be selected according to the requirement either as food materials or for processing of bitter melon.
\end{abstract}

Key words : bitter melon, drying method, quality characteristics, antioxidant activity

\section{서 론}

여주(Momordica charantia L.)는 박과에 속하는 일년 생 덩굴성 식물로 미국에서는 bitter melon(bitter gound), 아프 리카에서는 wild cucumber, 인도에서는 karela, 동남아시아

*Corresponding author. E-mail : yoonky2441@ynu.ac.kr Phone : 82-53-810-2878, Fax : 82-53-810-4666

Received 22 November 2018; Revised 29 January 2019; Accepted 8 March 2019.

Copyright (c) The Korean Society of Food Preservation. All rights reserved.
에서는 ampalaya 등 다양한 이름으로 불리고 있다. 일본과 미국에서는 차, 음료 및 건강보조식품의 재료로 이용되고 있으며(1), 중국에서는 약용식물로서 외상 치료 및 궤양의 치료에 사용되고 있다(2). 동남아시아 지역에서는 여주가 피부병, 야맹증, 구충, 류머티스, 복통, 황달, 월경촉진 등에 도 효과가 있는 것으로 알려져 널리 이용되고 있다(3-5). 여주는 표면에 혹 같은 돌기가 많을수록 쓴맛이 강하며, 아미노산, 비타민, 무기질, 식이섬유 및 $\beta$-carotene의 함량 이 풍부하다 $(6,7)$. 여주의 기능성 성분으로는 alkaloids, triterpenoids, phenolic acids, flavonoids, saponins, carotenoids 등이 알려져 있다(8-10). 다양한 기능성 성분의 작용으로 
여주는 항당뇨 효과, 항산화 활성, 항균 및 항발암 효과, 항염증 활성, 콜레스테롤 저하 등의 다양한 생리활성을 가 지는 것으로 보고되었다(11-13). 이와 같이 여주의 기능성 및 생리활성에 관한 연구는 많으나 기초적인 식품학적 특성 에 관한 연구는 부족한 실정이다. 또한 여주는 다양한 기능 성분을 다량 함유하고 있음에도 불구하고 생으로 섭취 시 쓴맛과 떫은맛으로 인해 식품으로서의 이용에 한계를 가진 다. 여주의 쓴맛은 식물스테롤 배당체를 비롯한 아미노산, 갈락트론산, 시트롤린, 펙틴 등이 관여하는 것으로 알려져 있으며(1), 건조하여 섭취할 경우 쓴맛과 떫은맛이 일부 감소된다. 따라서 여주의 식품 재료로의 활용성 증가를 위 한 다양한 건조방법에 따른 특성 연구가 필요하다.

식품의 건조는 효소와 미생물에 의한 부패나 변질을 방 지하고 식품의 저장성 및 수송성을 향상시키기 위하여 사용 되며, 건조방법에는 천일건조, 열풍건조, 적외선건조, 동결 건조 방법 등이 있다(14). 천일건조는 자연환경을 이용한 건조방법으로 비용이 저렴하나 기상조건의 영향을 많이 받고 장기간의 건조시간이 필요하다(15). 열풍건조는 건조 시간이 빠르고 경제적인 반면, 열로 인해 식품의 수축이 나타나고, 텍스처 저하 및 갈변으로 인한 색상 변화가 따른 다(14). 적외선 건조는 0.75-400 $\mu \mathrm{m}$ 범위의 파장을 이용하여 수분을 제거하는 방법으로 비타민의 파괴가 적으며 향이나 맛이 변하지 않고, 식품의 균일한 건조가 가능하다(16). 동 결건조는 건조된 제품의 향, 물성 및 영양성분의 변화가 적으며, 제품의 품질이 우수한 특성을 가지는 효과적인 건 조법이라고 할 수 있으나 시설 및 건조비용이 고가이다(17).

본 연구에서는 여주의 식품으로서의 활용성을 높이고자 다양한 방법으로 건조하고 각 건조방법에 따른 여주의 품질 특성 및 항산활 활성을 측정하였다. 즉, 여주를 천일, 열풍, 동결 및 적외선을 이용하여 건조하고, 이후 각 건조방법에 따른 이화학적 특성, 기능성 성분의 함량 및 항산화 활성을 측정하여 여주의 품질을 향상시킬 수 있는 건조방법을 찾고 식품으로서의 활용성 증진을 위한 기초자료 제공하고자 하였다.

\section{재료 및 방법}

\section{실험재료}

본 실험에서 사용된 여주(Momordica charantia)는 2016 년 강원도 홍천에서 수확한 열매를 한방전문 쇼핑몰 천년약 초에서 구입하였으며, 세척한 후 $1 \mathrm{~cm}$ 의 두께로 균일하게 slice한 후 각 건조방법에 따라 건조되었다. 각각의 방법으 로 건조된 여주는 분쇄기(IKA A11 basic, IKA-Werke $\mathrm{GmbH}$, Staufen, Germany)를 사용하여 $40 \mathrm{mesh}$ 로 분쇄한 후 이화학적 특성 분석용 시료로 사용되었다.

\section{건조 방법}

여주 열매는 천일건조(sun drying, SD), 열풍건조(hot-air drying, $\mathrm{HD}$ ), 적외선건조(infrared drying, ID), 동결건조 (freeze drying, FD) 방법을 이용하여 건조되었다. 천일건조 는 일광을 이용하여 일정한 장소에서 3 일간 건조하였으며, 열풍건조는 hot-air dryer(IRD-250, Woori Sci, Pocheon, Korea)를 사용하여 적외선을 작동하지 않은 상태로 $55^{\circ} \mathrm{C}$ 의 온도에서 14 시간 건조하였으며, 적외선건조는 infrared dryer(IRD-250, Woori Sci)를 사용하여 $55^{\circ} \mathrm{C}$ 에서 8시간 건 조하였다. 동결건조는 freeze dryer(SFDSM12, Samwon, Seoul, Korea)를 사용하여 건조하였다. 이때 각 건조물의 최종수분함량이 일정수분함량( $10 \%$ 이하)이 될 때까지 건 조하였다.

\section{수분함량, $\mathrm{pH}$ 및 적정산도}

수분함량은 적외선수분측정기(HG53, Mettler Toledo, Greifensee, Switzerland)를 이용하여 측정하였다. $\mathrm{pH}$ 는 Kim 등(18)의 방법에 따라 시료 $3 \mathrm{~g}$ 에 증류수 $30 \mathrm{~mL}$ 를 가한 후 homogenizer(Nissei AM-12, Nohonseiki Kaisha Co., Tokyo, Japan)로 $10,000 \mathrm{rpm}$ 에서 10 분간 마쇄하여 $20^{\circ} \mathrm{C}$ 에서 2시간 방치 후 여과하여 $\mathrm{pH}$ meter(Toledo Gmbh HG53, Switzerland)를 이용하여 측정하였으며, 적정산도는 시료 $5 \mathrm{~g}$ 을 취해 $50 \mathrm{~mL}$ 의 증류수를 가한 후 homogenizer(Nissei AM-12, Nohonseiki Kaisha Co.)로 10,000 rpm에서 10분간 마쇄하여 $20^{\circ} \mathrm{C}$ 에서 3 시간 방치한 다음 여과하여 $0.01 \mathrm{~N}$ $\mathrm{NaOH}$ 로 적정하여 소비된 양을 citric acid로 환산하였다.

\section{가용성 고형분 및 환원당 함량}

가용성 고형분 함량은 $\mathrm{Kim}$ 등(18)의 방법에 준하여 시료 $3 \mathrm{~g}$ 을 취해 $30 \mathrm{~mL}$ 가한 후 homogenizer(Nissei AM-12, Nohonseiki Kaisha Co.)로 $10,000 \mathrm{rpm}$ 에서 10 분간 마쇄하여 $20^{\circ} \mathrm{C}$ 에서 2시간 방치 후 여과하여 당도계(N-1a, Atago Co., Tokyo, Japan)를 이용하여 측정하였다.

환원당 함량은 dinitrosalicylic acid(DNS)법에 따라 시험 하였다. 즉, 시료 $1 \mathrm{~g}$ 을 50 배 $(\mathrm{v} / \mathrm{w})$ 의 증류수에 혼합하여 Sonicator(2210R-Dth, Branson yhasonic Co., Danbury, CT, $\mathrm{USA}$ )를 이용하여 30 분간 추출하였다. $4^{\circ} \mathrm{C}, 8,000 \mathrm{rpm}$ 에서 20 분동안 원심분리(Supra-21K, Hanil, Incheon, Korea)하여 얻은 상층액을 증류수를 이용하여 $50 \mathrm{~mL}$ 로 정용하였다. 시험관에 추출액 $1 \mathrm{~mL}$ 와 dinitrosalicylic acid(DNS) 시약을 $1 \mathrm{~mL}$ 를 넣고, 끓는 물에서 10 분 동안 중탕시켜 상온에서 충분히 냉각시킨 다음 증류수 $3 \mathrm{~mL}$ 를 넣어 $550 \mathrm{~nm}$ 에서 흡광도를 측정하였다. 이때 환원당 함량은 glucose(SigmaAldrich Co., St. Louis, MO, USA)를 표준물질로 하여 작성 한 검량선으로부터 환산하였다. 


\section{유리아미노산 함량 측정}

유리아미노산 측정용 시료는 환원당 함량 측정을 위한 시료 추출방법과 같은 방법으로 추출하여 사용하였다. 즉, sonicator(2210R-Dth, Branson Yhasonic Co., Danbury, CT, $\mathrm{USA}$ )를 이용하여 추출 후 원심분리된 상등액의 일정량을 $0.45 \mu \mathrm{L}$ membrane filter(Milipore, Billeria, MA, USA)로 여 과한 후 amino acid analyzer(L-8800, Hitach, Tokyo, Japan) 로 분석하였다.

\section{추출물 제조}

기능성 성분의 함량 및 항산화 활성 측정을 위하여 건조 분말에 $70 \%$ 에탄올을 $1: 10$ 의 비율로 넣고 상온에서 1 일간 추출하였다. 이후 추출물을 filter paper(Whatman No.1, Maidstone, England)로 여과하고 농축한 후 동결건조 하였 으며, 건조된 추출물을 폴리페놀, 플라보노이드 및 항산화 활성 측정용 시료로 사용되었다.

\section{폴리페놀 및 플라보노이드 함량 측정}

폴리페놀 함량은 Dewanto 등(19)의 방법에 따라 에탄올 추출물 $100 \mu \mathrm{L}$ 에 $2 \%$ sodium carbonate $2 \mathrm{~mL}$ 과 $50 \%$ Folin-Ciocalteu reagent $100 \mu \mathrm{L}$ 을 가한 후 $720 \mathrm{~nm}$ 에서 흡광 도를 측정하였으며, gallic acid(Sigma-Aldrich Co.)의 검량 선에 의하여 함량을 산출하였다.

플라보노이드 함량은 Abdel-Hameed(20)의 방법에 따라 측정하였다. 즉, 시료 $100 \mathrm{~mL}$ 에 $5 \%$ sodium nitrite $0.15 \mathrm{~mL}$ 을 가한 후 $25^{\circ} \mathrm{C}$ 에서 6 분간 방치한 다음 $10 \%$ aluminium chloride $0.3 \mathrm{~mL}$ 를 가하여 $25^{\circ} \mathrm{C}$ 에서 5 분간 방치하였다. 다음 $1 \mathrm{~N} \mathrm{NaOH} 1 \mathrm{~mL}$ 를 가하고 vortex상에서 가한 후 $510 \mathrm{~nm}$ 에서 흡광도를 측정하였으며 rutin hydrate(Sigma-Aldrich Co.)의 검량선에 의하여 함량을 산출하였다.

\section{$\mathrm{DPPH}$ 라디칼 소거활성}

$\mathrm{DPPH}$ 라디칼 소거활성은 Jang 등(21)의 방법에 의하여 실험하였다. 에탄올 추출물 $0.2 \mathrm{~mL}$ 에 $0.4 \mathrm{mM}$ 1,1-diphenyl-2-picryl-hydrazyl(DPPH) 용액 $0.8 \mathrm{~mL}$ 를 가하 여 10 분간 방치한 다음 $525 \mathrm{~nm}$ 에서 분광광도계(UV1650PC, Shimadzu, Kyoto, Japan)를 이용하여 흡광도의 변 화를 측정하였으며, DPPH radical scavenging activity(\%)= 100 -[(absorbance of sample/absorbance of control $) \times 100]$ 에 의하여 활성도를 산출하였다.

\section{ABTS 라디칼 소거활성 측정}

건조여주 에탄올 추출물의 $\mathrm{ABTS}$ 라디칼 소거활성은 $\mathrm{Oh}$ 등(22)의 방법에 따라 $7.4 \mathrm{mM}$ 2,2'-azino-bis(3ethylbenzothiazoline-6-sulfonic acid) diammonium salt(ABTS) 와 $2.6 \mathrm{mM}$ potassium persulfate를 혼합하여 실온 - 암소에서 24시간 동안 방치하여 라디칼을 형성시킨 다음 실험 직전
에 $\mathrm{ABTS}$ 용액을 $732 \mathrm{~nm}$ 에서 흡광도가 $0.700 \pm 0.030$ 이 되도 록 phosphate buffer saline(PBS, $\mathrm{pH}$ 7.4)로 희석하여 사용하 였다. 희석된 용액 $950 \mu \mathrm{L}$ 에 추출물 $50 \mu \mathrm{L}$ 를 가하여 암소에 서 10 분간 반응시킨 후 $732 \mathrm{~nm}$ 에서 흡광도를 측정하였으며 계산식, ABTS radical scavenging activity $(\%)=100-[$ (absorbance of sample/absorbance of control) $\times 100]$ 에 의하여 활성도를 산출하였다.

\section{환원력 측정}

건조여주 에탄올 추출물의 환원력은 $\mathrm{Oh}$ 등(22)의 방법에 따라 시료 $1 \mathrm{~mL}$ 에 $0.2 \mathrm{M}$ phosphate buffer( $\mathrm{pH}$ 6.6) $2.5 \mathrm{~mL}$ 와 $1 \%$ potassium ferricyanide 용액 $2.5 \mathrm{~mL}$ 를 가한 후 $50^{\circ} \mathrm{C}$ 에서 30 분간 반응시켰다. 다음에 $10 \%$ trichloroacetic acid(TCA) 용액 $2.5 \mathrm{~mL}$ 를 가한 후 $1,650 \times g$ 에서 10 분간 원심분리 하였 으며, 상층액 $2.5 \mathrm{~mL}$ 에 증류수 $2.5 \mathrm{~mL}$ 와 $0.1 \% \mathrm{FeCl}_{3}$ 용액 $0.5 \mathrm{~mL}$ 를 가한 후 $700 \mathrm{~nm}$ 에서 흡광도를 측정하였다.

\section{통계처리}

유리아미노산 함량(2회)을 제외한 모든 실험은 3회 반복 으로 행하여 평균치와 표준편차로 나타내었고, 유의성 검 증은 version 12의 SPSS(Statistical Package for Social Sciences, SPSS Inc., Chicago, IL, USA) software package program을 이용하여 $\mathrm{p}<0.05$ 수준에서 Duncan's multiple range test를 행하였다.

\section{결과 및 고찰}

\section{이화학적 특성}

건조방법에 따른 건조 여주의 수분함량, 가용성 고형분 함량, $\mathrm{pH}$, 적정산도 및 환원당 함량을 측정한 결과는 Table 1 과 같다. 천일건조, 열풍건조, 동결건조, 적외선건조된 여 주의 수분함량은 각각 $9.85 \%, 5.04 \%, 5.36 \%$ 및 $7.69 \%$ 로 천일건조의 수분함량이 유의적으로 가장 높았다. 또한 동 결건조와 열풍건조가 낮은 수분함량을 보였으며, 두 건조 방법 간의 유의적인 차이는 없는 것으로 나타났다. 가용성 고형분 함량은 동결건조가 $1.27{ }^{\circ} \mathrm{Brix}$ 로 가장 높았으며, 천 일건조는 $1.26{ }^{\circ} \mathrm{Brix}$, 열풍건조와 적외선건조는 $1.12{ }^{\circ} \mathrm{Brix}$ 로 건조방법에 따른 유의적인 차이는 없었다. Silva 등(23) 은 여주에 함유된 가용성 고형분 함량을 측정한 결과, 4.04 ${ }^{\circ} \mathrm{Brix}$ 로 보고하여 본 연구와 차이를 보였다. 가용성 고형분 의 함량은 과일 및 채소에 용해되어 있는 당을 비롯한 염분, 단백질, 유기산 등의 함량을 나타내는 것으로, 주로 각종 과일이나 채소류의 당도를 나타낸다. 일반적으로 가용성 고형분의 함량이 높을수록 추출 수율이 높을 뿐만 아니라, 이와 함께 높은 당도에 의한 단맛의 부여로 기호성을 높일 수 있다(24). 
Table 1. Physicochemical properties of Momordica charantia according to different drying methods

\begin{tabular}{|c|c|c|c|c|c|}
\hline Drying methods ${ }^{1)}$ & $\begin{array}{c}\text { Moisture } \\
\text { content }(\%)\end{array}$ & $\begin{array}{l}\text { Soluble solid content } \\
\text { ( }{ }^{\circ} \text { Brix) }\end{array}$ & $\mathrm{pH}$ & Titratable acidity ${ }^{2}(\%)$ & $\begin{array}{l}\text { Reducing sugar content } \\
\text { (mg/100 g-dry weight) }\end{array}$ \\
\hline SD & $9.85 \pm 0.26^{3(24)}$ & $1.26 \pm 0.06^{\mathrm{NS} 5)}$ & $4.57 \pm 0.02^{b}$ & $0.63 \pm 0.02^{b}$ & $280.48 \pm 9.19^{\mathrm{a}}$ \\
\hline $\mathrm{HD}$ & $5.04 \pm 0.01^{\mathrm{c}}$ & $1.12 \pm 0.12$ & $4.62 \pm 0.04^{\mathrm{b}}$ & $0.61 \pm 0.03^{\mathrm{b}}$ & $220.33 \pm 4.72^{\mathrm{c}}$ \\
\hline FD & $5.36 \pm 0.29^{c}$ & $1.27 \pm 0.18$ & $4.79 \pm 0.03^{\mathrm{a}}$ & $0.60 \pm 0.01^{b}$ & $247.13 \pm 5.87^{b}$ \\
\hline ID & $7.69 \pm 0.30^{b}$ & $1.12 \pm 0.06$ & $4.38 \pm 0.06^{\mathrm{c}}$ & $0.69 \pm 0.03^{\mathrm{a}}$ & $231.45 \pm 8.78^{c}$ \\
\hline
\end{tabular}

${ }^{1)} \mathrm{SD}$, sun drying; $\mathrm{HD}$, hot-air drying; $\mathrm{FD}$, freeze drying; $\mathrm{ID}$, infrared drying.

${ }^{2)}$ Titratable acidity was expressed as percent of organic acid calculated as citric acid.

${ }^{3)}$ Values are means \pm SD of triplicate determinations.

${ }^{4}$ Different superscripts within a column indicate significant differences at $\mathrm{p}<0.05$.

${ }^{5}$ Not significant.

천일건조, 열풍건조, 동결건조, 적외선건조 추출물의 $\mathrm{pH}$ 는 모두 산성으로 나타났으며, 적외선건조의 $\mathrm{pH}$ 는 4.38 , 천일건조의 $\mathrm{pH}$ 는 4.57 열 풍건조의 $\mathrm{pH}$ 는 4.62 , 동결건조의 $\mathrm{pH}$ 는 4.79로 모두 낮은 $\mathrm{pH}$ 를 나타내었다. 적정산도는 적외 선건조가 $0.69 \%$ 로 유의적으로 가장 높았으며, 천일건조 $0.63 \%$, 열풍건조 $0.61 \%$ 및 동결건조 $0.60 \%$ 로 적외선건조 외 모든 시료에서는 유의적인 차이가 없었다. Ozdemir 등 (25)은 숙성단계별 여주의 $\mathrm{pH}$ 와 적정산도를 측정한 결과, $\mathrm{pH}$ 는 4.10-4.46, 적정산도는 0.11-0.16\%의 범위로 측정되었 다고 보고하였다. 또한 Abdullah와 Anna(26)도 여주를 숙성 단계별로 채취하여 $\mathrm{pH}$ 와 적정산도를 측정한 결과, $\mathrm{pH}$ 와 적정산도는 각각 4.86-5.20, $1.43-2.00 \%$ 의 범위로 나타났다. Dipali Dhotre 등(27)은 천일건조 및 캐비넷건조된 여주의 적정산도를 측정한 결과, 각각 $1.10 \%$ 와 $0.80 \%$ 로 보고하여 본 연구결과에 비해 높은 값을 보였다. 이와 같이 여주의 $\mathrm{pH}$ 와 적정산도가 다른 것은 품종 및 재배 환경에 따른 영향 으로 판단된다.

건조방법에 따른 건조 여주의 환원당 함량은 천일건조 $280.48 \mathrm{mg} / 100 \mathrm{~g}$, 동결건조 $247.13 \mathrm{mg} / 100 \mathrm{~g}$, 적외선건조 $231.45 \mathrm{mg} / 100 \mathrm{~g}$, 열풍건조 $220.33 \mathrm{mg} / 100 \mathrm{~g}$ 으로 나타났다. 숙성 별로 채취된 여주의 환원당 함량을 측정한 결과, 녹색 과 $1.04 \%$ 에서 완숙과의 경우 $1.37 \%$ 의 범위로 나타나 본 연구결과에 비해 다소 높게 측정되었다(25). 냉풍건조, 열 풍건조 및 천일건조에 의해 건조된 무의 환원당 함량은 $16.5-17.1 \mathrm{mg} / 100 \mathrm{~g}$ 의 범위로 측정되었으며 냉풍건조가 천 일건조에 비해 유의적으로 높은 환원당 함량을 나타내어 (28), 본 연구결과와 다소 차이를 보였다. 일반적으로 환원 당 함량은 건조제품의 품질 중 색도에 영향을 주는 주요 요인이며 환원당 함량이 많을수록 비효소적 갈변반응이 촉진되어 색이 검어진다고 한다.

\section{아미노산 함량}

건조방법에 따른 건조 여주의 아미노산 함량을 분석한 결과는 Table 2 와 같다. 총 아미노산의 함량은 동결건조 $1,211.88 \mathrm{mg} / 100 \mathrm{~g}$, 적외선건조 $1,123.84 \mathrm{mg} / 100 \mathrm{~g}$, 천일건
조 $1,083.37 \mathrm{mg} / 100 \mathrm{~g}$, 열풍건조 $1,007.78 \mathrm{mg} / 100 \mathrm{~g}$ 로 측정되 어 동결건조 시 가장 높은 아미노산 함량을 나타내었다. 붉은 대게를 다양한 방법으로 건조하여 유리아미노산의 함량을 측정한 결과(29), 생육에 비해 동결건조 시 유리아미 노산 함량 감소가 가장 작았으며, 열풍건조 시 함량 감소가 가장 크게 나타나 본 연구결과와 같았다. 또한 열풍건조 시 유리아미노산의 함량 감소는 가열건조에 의해 단백질의 유출손실과 가열분해에 의한 것으로 보고하였다(29). 건조 여주의 필수아미노산 함량은 적외선건조가 가장 높았고, 다음으로 열풍건조, 동결건조, 천일건조 순으로 나타내었 다. 비필수아미노산의 함량은 동결건조 $776.86 \mathrm{mg} / 100 \mathrm{~g}$ 으 로 가장 높았으며, 천일건조 $679.69 \mathrm{mg} / 100 \mathrm{~g}$, 적외선건조 $608.50 \mathrm{mg} / 100 \mathrm{~g}$, 열풍건조 $570.18 \mathrm{mg} / 100 \mathrm{~g}$ 으로 측정되었 다. 아미노산 조성 중 쓴맛을 나타낸다고 알려진 arginine의 함량이 열풍건조 $361.99 \mathrm{mg} / 100 \mathrm{~g}$, 적외선건조 343.89 $\mathrm{mg} / 100 \mathrm{~g}$, 천일건조 $296.42 \mathrm{mg} / 100 \mathrm{~g}$, 동결건조 279.31 $\mathrm{mg} / 100 \mathrm{~g}$ 로 매우 높은 값을 보였다. 이는 여주 쓴맛의 원인 중 하나가 높은 arginine 함량에 기인하는 것으로 판단된다. 또한 건조방법 중에서는 열풍건조가 가장 높은 arginine 함량을 나타내어 열풍건조된 여주의 쓴맛이 강할 것으로 생각된다.

유리아미노산은 생체활성물질의 구성성분이며, 맛을 내 는 중요한 성분이다. 유리아미노산은 감칠맛계(aspartic acid, glutamic acid), 단맛계(threonine, serine, glutamine, proline, glycine, alanine, lysine), 그리고 쓴맛계(valine, methionine, isoleucine, leucine, phenylalanine, histidine, arginine), 황 화합물과 비슷한 맛(cysteine, methionine)으로 분류되기도 한다(30). 따라서 여주의 유리아미노산 중 맛 특성에 따라 분류하여 나타낸 결과는 Table 3 과 같다. 감칠 맛(MSG-like)의 경우 천일건조 $171.34 \mathrm{mg} / 100 \mathrm{~g}$, 동결건조 $138.44 \mathrm{mg} / 100 \mathrm{~g}$, 적외선건조 $49.48 \mathrm{mg} / 100 \mathrm{~g}$, 열풍건조 $37.86 \mathrm{mg} / 100 \mathrm{~g}$ 로 천일건조 시 가장 높게 나타났다. 단맛 (sweet)은 동결건조 $281.59 \mathrm{mg} / 100 \mathrm{~g}$, 적외선건조 222.81 $\mathrm{mg} / 100 \mathrm{~g}$, 천일건조 $165.69 \mathrm{mg} / 100 \mathrm{~g}$, 열 풍건조 158.32 $\mathrm{mg} / 100 \mathrm{~g}$ 로 동결건조와 적외선건조에서 높게 나타났다. 
Table 2. Free amino acid contents of Momordica charantia according to different drying methods

(mg/100 g-dry weight)

\begin{tabular}{|c|c|c|c|c|c|}
\hline \multirow{2}{*}{\multicolumn{2}{|c|}{ Amino acid }} & \multicolumn{4}{|c|}{ Drying methods ${ }^{1)}$} \\
\hline & & SD & $\mathrm{HD}$ & FD & ID \\
\hline \multirow{8}{*}{ Essential amino acid } & Isoleucine & $47.65 \pm 2.62$ & $58.38 \pm 0.59$ & $43.09 \pm 1.08$ & $64.78 \pm 1.05$ \\
\hline & Leucine & $62.57 \pm 1.33$ & $49.64 \pm 1.52$ & $45.73 \pm 0.15$ & $64.21 \pm 1.65$ \\
\hline & Lysine & $72.75 \pm 1.58$ & $51.63 \pm 2.11$ & $44.42 \pm 0.89$ & $63.72 \pm 2.25$ \\
\hline & Methionine & $11.90 \pm 2.13$ & $6.14 \pm 0.21$ & $20.88 \pm 1.90$ & $3.74 \pm 0.08$ \\
\hline & Phenylalanine & $70.80 \pm 2.63$ & $69.28 \pm 1.38$ & $67.37 \pm 2.58$ & $76.26 \pm 1.52$ \\
\hline & Threonine & $52.81 \pm 3.01$ & $81.29 \pm 2.96$ & $45.03 \pm 2.35$ & $101.31 \pm 2.89$ \\
\hline & Tryptophan & $77.78 \pm 0.17$ & $52.76 \pm 2.52$ & $98.75 \pm 1.52$ & $55.88 \pm 0.82$ \\
\hline & Valine & $7.41 \pm 1.11$ & $68.49 \pm 0.52$ & $69.74 \pm 0.99$ & $85.43 \pm 3.02$ \\
\hline \multicolumn{2}{|c|}{ Total essential amino acid } & $403.68 \pm 2.51$ & $437.60 \pm 3.74$ & $435.0 \pm 2.12$ & $515.34 \pm 1.58$ \\
\hline \multirow{8}{*}{ Non-essential amino acid } & Alanine & $57.28 \pm 4.20$ & $43.92 \pm 1.05$ & $140.74 \pm 1.20$ & $69.37 \pm 1.05$ \\
\hline & Arginine & $296.42 \pm 2.01$ & $361.9 \pm 2.11$ & $279.31 \pm 1.85$ & $343.89 \pm 2.95$ \\
\hline & Aspartic acid & $60.75 \pm 2.62$ & $33.42 \pm 1.01$ & $92.56 \pm 1.25$ & $42.56 \pm 3.56$ \\
\hline & Glutamic acid & $110.59 \pm 3.22$ & $4.44 \pm 0.51$ & $45.88 \pm 2.56$ & $6.92 \pm 0.58$ \\
\hline & Glycine & $17.44 \pm 1.50$ & $7.54 \pm 0.28$ & $26.42 \pm 3.12$ & $12.74 \pm 1.11$ \\
\hline & Histidine & $46.69 \pm 0.52$ & $57.72 \pm 0.72$ & $52.98 \pm 0.95$ & $57.79 \pm 2.02$ \\
\hline & Serine & $38.16 \pm 2.10$ & $25.57 \pm 1.55$ & $69.40 \pm 5162$ & $39.39 \pm 2.89$ \\
\hline & Tyrosine & $52.36 \pm 1.62$ & $35.58 \pm 1.56$ & $69.57 \pm 1.25$ & $35.84 \pm 3.25$ \\
\hline \multicolumn{2}{|c|}{ Total non-essential amino acid } & $679.69 \pm 1.85$ & $570.18 \pm 2.10$ & $776.86 \pm 0.35$ & $608.50 \pm 1.85$ \\
\hline \multicolumn{2}{|c|}{ Total amino acids (g/100 g-dry weight) } & $1,088.37 \pm 2.89$ & $1,007.78 \pm 1.85$ & $1,211.88 \pm 2.78$ & $1,123.84 \pm 1.96$ \\
\hline
\end{tabular}

${ }^{1)} \mathrm{SD}$, sun drying; $\mathrm{HD}$, hot-air drying; $\mathrm{FD}$, freeze drying; $\mathrm{ID}$, infrared drying.

Table 3. Free amino acid contents of Momordica charantia according to taste characteristics

(mg/100 g-dry weight)

\begin{tabular}{ccccc}
\hline \multirow{2}{*}{$\begin{array}{c}\text { Taste } \\
\text { characteristics }\end{array}$} & \multicolumn{4}{c}{ Drying methods $^{2)}$} \\
\cline { 2 - 5 } & $\mathrm{SD}$ & $\mathrm{HD}$ & $\mathrm{FD}$ & $\mathrm{ID}$ \\
\hline MSG-like & $171.34 \pm 2.85$ & $37.86 \pm 3.45$ & $138.44 \pm 2.55$ & $49.48 \pm 2.52$ \\
Sweet & $165.69 \pm 1.89$ & $158.32 \pm 1.44$ & $281.59 \pm 1.52$ & $222.81 \pm 2.02$ \\
Bitter & $573.57 \pm 1.25$ & $666.02 \pm 1.08$ & $634.76 \pm 2.85$ & $687.20 \pm 1.02$ \\
Tasteless & $125.11 \pm 2.85$ & $87.21 \pm 2.82$ & $113.99 \pm 0.89$ & $99.56 \pm 0.85$ \\
\hline
\end{tabular}

${ }^{11}$ MSG-like (monosodium glutamate-like), Asp+Glu; Sweet, Ala+Gly+Pro+Ser+Thr; Bitter, Arg+His+Ile+Leu+Met+Phe+Pro+Trp+Val; Tasteless, Lys+Tyr.

${ }^{2)} \mathrm{SD}$, sun drying; $\mathrm{HD}$, hot-air drying; FD, freeze drying; ID, infrared drying.

쓴맛(bitter)은 적외선건조가 $687.20 \mathrm{mg} / 100 \mathrm{~g}$ 로 가장 높은 값을 나타내었으며, 열풍건조 $666.02 \mathrm{mg} / 100 \mathrm{~g}$, 동결건조 $634.76 \mathrm{mg} / 100 \mathrm{~g}$, 천일건조 $573.57 \mathrm{mg} / 100 \mathrm{~g}$ 로 측정되었다. 이상과 같이 모든 건조방법에서 여주는 단맛 또는 감칠맛을 내는 아마노산에 비해 쓴맛을 내는 아미노산의 함량이 매우 높음을 알 수 있었다. 특히 적외선건조 시 쓴맛을 내는 아미 노산의 함량이 매우 높아 여주의 쓴맛을 감소시키기 위한 건조방법으로 바람직하지 못한 것으로 판단된다. 반면 천
일건조 시 쓴맛을 나타내는 아미노산의 비율이 낮게 나타났 으며, 또한 동결건조 시 감칠맛과 단맛을 내는 아미노산의 비율이 다른 건조방법에 비해 높게 나타난 것을 알 수 있었다.

\section{폴리페놀 및 플라보노이드 함량}

건조방법에 따른 여주 에탄올 추출물의 폴리페놀 및 플 라보노이드 함량을 측정한 결과는 Table 4 와 같다. 폴리페 놀 함량은 천일건조, 열풍건조, 동결건조 및 적외선건조 시 각각 $2.75 \mathrm{mg} \mathrm{GAE} / \mathrm{g}, 3.40 \mathrm{mg} \mathrm{GAE} / \mathrm{g}, 2.83 \mathrm{mg} \mathrm{GAE} / \mathrm{g}$ 및 $3.13 \mathrm{mg} \mathrm{GAE} / \mathrm{g}$ 으로 열풍건조 시 가장 높은 함량을 보였 으나 적외선건조와 유의적인 차이는 없었다. 플라보노이드 함량은 천일건조, 열풍건조, 동결건조 및 적외선건조가 각 각 $1.45 \mathrm{mg} \mathrm{RE} / \mathrm{g}, 1.54 \mathrm{mg} \mathrm{RE} / \mathrm{g}, 1.47 \mathrm{mg} \mathrm{RE} / \mathrm{g}$ 및 1.65 $\mathrm{mg} \mathrm{RE} / \mathrm{g}$ 으로 적외선건조가 가장 높은 값을 나타내었으나 건조방법에 따른 유의적인 차이는 없었다. 성숙단계별 여 주의 폴리페놀 함량을 측정한 결과, 생과의 경우 2.8-4.8 $\mathrm{mg} \mathrm{GAE} / 100 \mathrm{~g}$ 이었으며, 건조과의 경우 $224-336 \mathrm{mg}$ $\mathrm{GAE} / 100 \mathrm{~g}$ 으로(26) 본 연구결과와 유사하였다. 반면, Ozdemir 등(25)은 여주 건조물의 폴리페놀 함량은 $5.62-8.25 \mathrm{mg} \mathrm{GAE} / \mathrm{g}$ 로 보고하여 본 연구결과에 비해 높은 함량을 보였다. 또한 Cha 등(31)은 여주의 메탄올 추출물에 
함유된 폴리페놀과 플라보노이드의 함량이 각각 $3.82 \%$ 와 $2.22 \%$ 였으며, 건조여주 $\mathrm{g}$ 당 각각 $6.24 \mathrm{mg}$ 및 $3.62 \mathrm{mg}$ 의 폴리페놀과 플라보노이드를 함유하고 있어, 본 연구결과에 비해 다소 높은 함량을 보였다. 여주의 폴리페놀 성분 중 catechin, P-comaric acid, tannic acid, ferulic acid, galic acid, caffeic acid 등은 우수한 항산화 효과가 있는 것으로 알려져 있다 $(32,33)$. 잣솔잎을 다양한 방법으로 건조시켜 제조한 분말 추출액의 총페놀 함량은 진공건조 및 동결건조 시 열풍건조에 비해 유의적으로 높았으며 $(\mathrm{p}<0.05)$, 플라보노 이드 함량은 열풍건조가 진공건조 및 동결건조에 비해 유의 적으로 높은 함량을 나타내어(34), 본 연구결과와 다소 차이 를 보였다. 반면, $\operatorname{Kim}$ 과 $\operatorname{Lee}(35)$ 는 톳 건조 시 열풍건조와 동결건조한 경우 폴리페놀 함량의 유의적인 차이가 없었으 며, 천일건조 한 톳의 폴리페놀 함량이 가장 낮다고 보고하 여 본 연구결과와 같았다. 이와 같이 천일건조에 의한 폴리 페놀의 낮은 함량은 햇빛의 영향으로 폴리페놀이 산화 파괴 되어 감소된 것으로 보고하였다.

Table 4. Total polyphenol and flavonoid contents of Momordica charantia according to different drying methods

\begin{tabular}{ccc}
\hline Drying methods $^{1)}$ & Polyphenol $\left(\mathrm{mg} \mathrm{GAE}^{2} / \mathrm{g}\right)$ & Flavonoid $\left(\mathrm{mg} \mathrm{RE}^{3)} / \mathrm{g}\right)$ \\
\hline SD & $2.75 \pm 0.03^{4) \mathrm{bs}}$ & $\left.1.45 \pm 0.01^{\mathrm{NS} 6}\right)$ \\
$\mathrm{HD}$ & $3.40 \pm 0.19^{\mathrm{a}}$ & $1.54 \pm 0.16$ \\
$\mathrm{FD}$ & $2.83 \pm 0.04^{\mathrm{b}}$ & $1.47 \pm 0.08$ \\
$\mathrm{ID}$ & $3.13 \pm 0.20^{\mathrm{a}}$ & $1.65 \pm 0.15$ \\
\hline
\end{tabular}

${ }^{1)} \mathrm{SD}$, sun drying; $\mathrm{HD}$, hot-air drying; $\mathrm{FD}$, freeze drying; $\mathrm{ID}$, infrared drying. ${ }^{2)} \mathrm{GAE}$, gallic acid equivalents.

${ }^{33} \mathrm{RE}$, rutin equivalents.

${ }^{4}$ Values are means $\pm \mathrm{SD}$ of triplicate determinations.

${ }^{5}$ Different superscripts within a column indicate significant differences at $\mathrm{p}<0.05$. ${ }^{6}$ Not significant.

\section{항산화 활성}

DPPH 라디칼 소거활성은 tocopherol, ascorbate, flavonoid 화합물, 방향족 아민류, Maillard형 갈변 생성물질, peptide 등 항산화 활성을 나타내는 생리활성 물질에 의해 DPPH 라디칼이 환원됨으로서 짙은 자색이 발색되는 정도에 따라 항산화 효과를 수소공여능으로 측정하는 방법이다(36). 건 조방법에 따른 여주의 DPPH 라디칼 소거활성을 측정한 결과는 Fig. $1 \mathrm{~A}$ 와 같다. 적외선건조가 모든 농도에서 가장 높은 라디칼 소거활성을 나타내었는데, 특히 $0.1 \mathrm{mg} / \mathrm{mL}$ 농도에서는 $\mathrm{DPPH}$ 라디칼 소거활성이 $16.07 \%$ 로 가장 높은 활성을 보였다. 열풍건조의 경우에도 $0.1,0.5$ 및 $1.0 \mathrm{mg} / \mathrm{mL}$ 농도에서 각각 $4.10 \%, 9.03 \%, 15.13 \%$ 의 $\mathrm{DPPH}$ 라디칼 소거 활성을 나타내어 적외선건조와 유의적인 차이를 보이지 않았다. 그리고 천일건조는 전체적으로 $\mathrm{DPPH}$ 라디칼 소거 활성이 낮은 것으로 나타내었다. 여주 메탄올 추출물의 $\mathrm{DPPH}$ 라디칼 소거능을 측정한 결과, $1 \mathrm{mg} / \mathrm{mL}$ 농도에서
약 $10 \%$ 의 소거능을 나타내어(31) 본 연구에 비해 낮은 활성 을 보였다. Kim과 Lee(35)는 건조방법에 따른 톳의 DPPH 라디칼 소거활성의 변화를 살펴본 결과 천일건조가 동결건 조, 열풍건조에 비해 유의적으로 활성이 감소한 것으로 보 고하여 본 연구결과와 유사하였다. 일반적으로 폴리페놀 함량과 항산화활성 간에 양의 상관관계가 있는 것으로 알려 져 있으며, 본 연구 결과에서는 이러한 경향을 나타내었다. 따라서 여주의 경우 열풍건조 및 적외선건조가 천일건조 및 동결건조에 비해 기능성 성분의 파괴를 줄이고 라디칼 소거활성을 유지하는 데 효율적인 건조방법으로 판단된다.

$\mathrm{ABTS}$ 라디칼 소거활성은 수소공여 항산화제(hydrogendonating antioxidants)와 연쇄절단형 항산화제(chain-breaking antioxidants) 모두를 측정할 수 있으며 수용상(aqueous phase)과 유기상(organic phase) 모두에 적용 가능한 측정방 법이다(36). 즉 ABTS 라디칼 소거활성은 lipophilic 또는 hydrophilic 항산화 물질의 측정에 적용 가능한 방법이다 (37). 여주의 건조방법에 따른 ABTS 라디칼 소거활성을 측정한 결과(Fig. $1 \mathrm{~B}$ ), $0.1 \mathrm{mg} / \mathrm{mL}$ 농도에서 열풍건조는 $14.74 \%$, 적외선건조는 $14.25 \%$ 로 두 건조방법 간 유의적인 차이는 없었다. 또한 $0.5 \mathrm{mg} / \mathrm{mL}$ 농도에서는 열풍건조, 동결 건조, 적외선건조의 $\mathrm{ABTS}$ 라디칼 소거활성이 각각 $49.63 \%, 46.56 \%, 52.00 \%$ 로 유의적인 차이가 없었다. 추출 물 $1.0 \mathrm{mg} / \mathrm{mL}$ 농도에서는 열풍건조의 ABTS 라디칼 소거활 성이 $78.08 \%$ 로 가장 높은 활성을 나타내었으며, 모든 시료 에서 $\mathrm{DPPH}$ 라디칼 소거능에 비해 높은 활성을 보였다. 이는 많은 페놀성 물질은 효과적으로 라디칼을 제거하나, 페놀물질의 종류에 따라 라디칼을 선택적으로 제거하는 것으로 보고되어(38), DPPH 라디칼보다 높은 소거능을 보 인 것으로 판단된다. 이러한 결과는 여주 품종별 항산화 활성을 측정한 결과, 폴리페놀 함량이 높을수록 $\mathrm{ABTS}$ 라디 칼 소거활성능이 높게 나타났으며, 또한 DPPH 라디칼 소거 능에 비해 ABTS 라디칼 소거능이 높게 나타난 Boo 등(13) 의 연구 결과와 일치하였다. 이상의 결과에서 여주 건조 시 열풍건조 및 적외선건조가 항산화 활성 유지에 효율적인 건조방법이 될 것으로 판단된다.

환원력 측정은 항산화작용의 여러 기작 중에서 활성 산 소종 및 유리기에 전자를 공여하는 능력을 말하며, $700 \mathrm{~nm}$ 에서 ferric-ferricyanide $\left(\mathrm{Fe}^{3+}\right)$ 혼합물이 수소를 공여하여 유 리라디칼을 안정화시켜 ferrous( $\left.\mathrm{Fe}^{2 \dagger}\right)$ 로 전환하는 환원력을 흡광도 값으로 나타내며, 환원력이 강할수록 푸른색을 띄 게 되므로 항산화 활성이 큰 물질일수록 높은 흡광도 값을 나타낸다(39). 건조방법에 따른 여주 추출물의 흡광도를 측정한 결과(Fig. 1C), $0.1 \mathrm{mg} / \mathrm{mL}$ 농도에서 0.13-0.16의 환 원력을 보였고, 0.5 및 $1.0 \mathrm{mg} / \mathrm{mL}$ 농도에서는 적외선건조 및 열풍건조가 높은 환원력을, 천일건조가 가장 낮은 환원 력을 나타내었다. 이는 건조방법에 따른 꾸지뽕 열매의 환 원력 측정 결과(40), 적외선건조와 열풍건조 추출물의 환원 
력이 동결건조보다 높게 나타난 결과와 유사하였다. 또한 이러한 결과는 DPPH 라디칼 소거 활성과 같이 환원력 또한 적외선건조 및 열풍건조 추출물의 높은 폴리페놀 함량에 기인한 것으로 판단된다. 이상의 결과 적외선건조 및 열풍 건조 방법이 다른 건조방법에 비해 높은 항산화 활성을
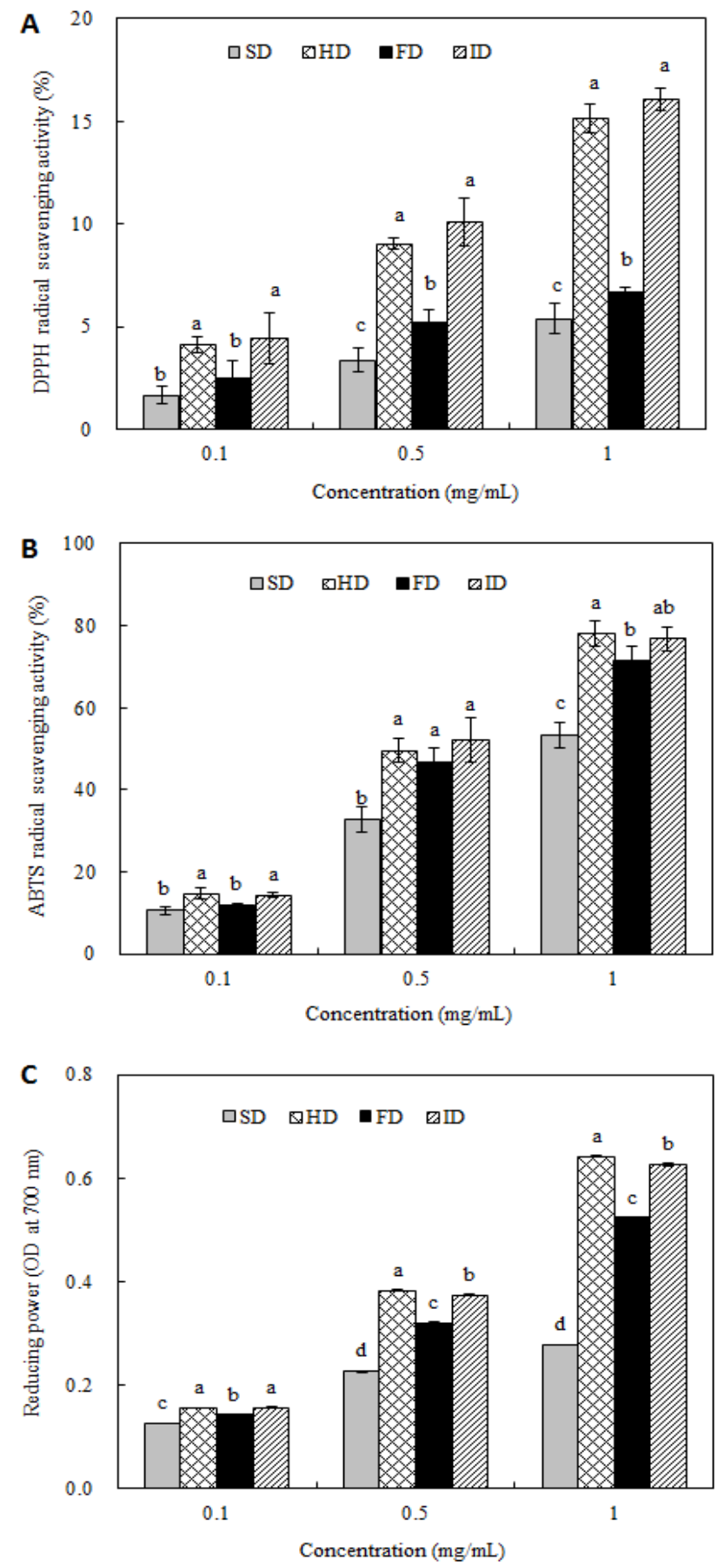

Fig. 1. Antioxidant activities of Momordica charantia extracts with different drying methods.

A, DPPH radical scavenging activity; B, ABTS radical scavenging activity; C, reducing power.

Values are means $\pm \mathrm{SD}$ of triplicate determinations. Different letter at the same concentration indicate significant differences $(\mathrm{p}<0.05)$.
타나냄을 알 수 있었다. 따라서 여주의 식품재료로서의 이 용 및 가공 목적에 따라 적절한 건조방법을 선택할 수 있을 것으로 판단된다.

\section{요 약}

본 연구는 다양한 생리활성을 지닌 여주의 식품으로서의 활용성을 향상시키기 위해 여러 가지 건조방법으로 건조한 뒤 이들의 품질 특성 및 항산화 활성을 측정하였다. 건조방 법에 따른 여주의 수분함량은 천일건조가 유의적으로 가장 높았다. 가용성 고형분 함량은 동결건조가 $1.27{ }^{\circ} \mathrm{Brix}$ 로 가 장 높았으며, 건조 여주의 $\mathrm{pH}$ 는 4.38-4.79를, 산도는 $0.60-0.69 \%$ 로 나타났다. 건조 여주의 환원당 함량은 $220.33-247.13 \mathrm{mg} / 100 \mathrm{~g}$ 으로 높은 함량을 나타내었다. 건조 여주의 총 아미노산의 총 함량은 동결건조 시 가장 높은 함량을 보였으며, 유리 아미노산 중 쓴맛을 가지는 arginine 의 함량이 가장 높았다. 건조 여주의 폴리페놀 함량은 열풍 건조 시 가장 높았으며, 플라보노이드 함량은 적외선건조 가 가장 높은 값을 나타내었으나 건조방법에 따른 유의적인 차이는 없었다. 항산화 활성의 경우 열풍건조와 적외선건 조 시 다른 건조방법에 비하여 유의적으로 높은 활성을 나타내었다. 이상의 결과, 동결건조 시 우수한 품질특성을 나타내었으며, 열풍건조 및 적외선건조 시 높은 항산화 활 성을 보였다. 따라서 여주의 식품재료 및 가공 목적에 따라 적절한 건조방법을 선택할 수 있을 것으로 판단된다. 향후 건조방법에 따른 건조여주의 쓴맛 감소효과를 정성적 및 정량적 분석을 위해 관능검사 및 쓴맛성분의 함량을 분석한 다면, 다양한 식품산업으로의 적용이 확대될 수 있을 것으 로 판단된다.

\section{References}

1. An SH (2014) Quality characteristics of muffin added with bitter melon (Momordica charantia L.) powder. Korean J Food Cook Sci, 30, 499-508

2. Gurbuz I, Akyuz C, Yesilada E, Sener B (2000) Anti-ulcerogenic effect of Momordica charantia L. fruits on various ulcer models in rats. J Ethnopharmacol, 71, 77-82

3. Srivastava Y, Venlcatakrishna-Bhatt H, Verma Y (1988) Effect of Monordica charantia Linn. pomous aqueous extract on cataractogenesis in murrin alloxan Diabetics. Pharmacol Res Commun, 20, 201-209

4. Virdi J, Sivakami S, Shahani S, Suthar AC, Banavalikar MM, Biyani MK (2003) Antihyperglycemic effects of 
three extracts from Momordica charantia. J Ethnopharmacol, 88, 107-111

5. Parkash A, Ng TB, Tso WW (2002) Purification and characterization of charantin, a napin-like ribosomeinactivating peptide from bitter gourd (Momordica charantia) seeds. J Peptide Res, 59, 197-202

6. Day C, Cartwright T, Provost J, Bailey CJ (1990) Hypoglycaemic effect of Momordica charantia extracts. Planta Med, 56, 426-435

7. Pugazhenthi S, Murthy SP (1995) Partial purification of a hypoglycemic fraction from the unripe fruits of Momordica charantia Linn (bitter gourd). Indian J Clin Biochem, 10, 19-22

8. Ahn MJ, Yuk HJ, Lee HY, Hwang CE, Jeong YS, Hong SY, Kwon OK, Kang SS, Kim HR, Park DS, Cho KM (2015) Effect of the enhanced biological activities and reduced bitter taste of bitter melon (Momordica charantia L.) by roasting. J Agric Life Sci, 49, 107-119

9. Moon SL, Choi SH (2014) Characteristic of cookies quality containing bitter melon (Momordica charantia L.) powder. Culi Sci Hos Res, 20, 80-90

10. Kim BK, Hong JS, Yoon HJ, Hong SD, Hong SP, Lee JI (2013) Influence of bitter melon extraction on oral squamous cell carcinoma. Kor J Oral Maxillofac Pathol, 37, 59-66

11. Kim MW (2013) Effect of bitter melon on plasma blood glucose and cholesterol levels in streptozotocin induced diabetic rats. J East Asian Soc Dietary Life, 23, 704-712

12. Nam SW, Kim MR (2015) A Study on inhibitory activities on carbohydrase and anti-inflammatory activities of hot-water and ethanol extracts from immature dried bitter melon (Momordica charantia L.). J East Asian Soc Dietary Life, 25, 999-1006

13. Boo HO, Lee HH, Lee JW, Hwang SJ, Park SU (2009) Different of total phenolics and flavonoids, radical scavenging activities and nitrite scavenging effects of Momordica charantia L. according to cultivars. Korean J Medicinal Crop Sci, 17, 15-20

14. Hong JH, Lee WY (2004) Quality characteristics of osmotic dehydrated sweet pumpkin by different drying methods. J Korean Soc Food Sci Nutr, 33, 1573-1579

15. Christopher GJ (1997) Industrial drying of food. Blackie Academic \& Professional, New York, NY, USA, p 1-6

16. Holdsworth SD (1971) Dehydration of food products: a review. J Food Technol, 6, 331-370

17. Litvin S, Mannheim CH, Miltz J (1998) Dehydration of carrots by a combination of freeze-drying, air or microwave heating and air or vacuum drying. J Food Eng, 36, 103-111

18. Kim HK, Lee BY, Shin DB, Kwon JH (1998) Effect of roasting conditions on physicochemical characteristics and volatile flavor components of chicory roots. Korean J Food Sci Technol, 30, 1279-1284

19. Dewanto V, Wu X, Adom KK, Liu RH (2002) Thermal processing enhances the nutritional value of tomatoes by increasing total antioxidant activity. J Agric Food Chem, 50, 3010-3014

20. Abdel-Hameed ESS (2008) Total phenolic contents and free radical scavenging activity of certain egyptian ficus species leaf samples. Food Chem, 114, 1271-1277

21. Jang HL, Shin SR, Yoon KY (2017) Isolation of antioxidant peptide from sandfish (Arctoscopus japonicus) roe hydrolysate. Korean J Food Preserv, 24, 542-549

22. Oh MH, Hwang YJ, Yoon KY (2017) Biological activity of water-soluble polysaccharides from Cedrela sinensis according to extraction methods. Korean J Food Sci Technol, 49, 215-221

23. Silva GMSW, Premathilaka ULRRW, Maduwanthi SDT, Uthpala TGG (2016). Development of fermented Momordica charantia and analysis of biochemical properties. Int J Sci Eng Res, 7, 362-366

24. Jan NE, Kawabata S (2011) Relationship between fruit soluble solid content and the sucrose concentration of the phloem sap at different leaf to fruit ratios in tomato. J Japan Soc Hort Sci, 80, 314-321

25. Ozdemir Y, Ozturk A, Tufekci S, Keskinel O, Kosti RI (2017) Physicochemical and nutritional properties of bitter melon at four maturation stages. Eurasian J Food Sci Technol, 1, 36-40

26. Abdullah A, Anna PK (2011) Influence of ripening stages on physicochemical charactristics and antioxidant properties of bitter gourd (Momorica charantia). Int Food Res J, 18, 895-900

27. Dipali Dhotre AM, Sonkamble AM, Kalaskar AB (2012) Effect of pre-treatments and drying methods on storage life of bitter gourd slices. Asian J Hort, 7, 101-103

28. Lee WY, Cha WS, Oh SL, Cho YJ, Lee HY, Lee BS, Park JS, Park JH (2006) Quality characteristics of dried radish (Raphanus sativus) by drying methods. Korean J Food Preserv, 13, 37-42

29. Yang CY (1999) Manufacturing conditions and quality of dried meat on the snow crab II. Change of weight loss, yield on the steaming and various drying method. 
Korean J Food Nutr, 12, 258-264

30. Solms J (1969) The taste of amino acids, peptides, and proteins. J Agric Food Chem, 17, 686-688

31. Cha JY, Jin JS, Cho YS (2011) Biological activity of methanolic extract from Ganoderma lucidum, Momordica charantia, Fagopyrum tataricum and their mixtrues. J Life Sci, 21, 1016-1024

32. Kubola J, Siriamornpun S (2008) Phenolic contents and antioxidant activities of bitter gourd (Momordica charantia L.) leaf, stem and fruit fraction extracts in vitro. Food Chem, 110, 881-890

33. Wu SJ, Ng LT (2007) Antioxidant and free radical scavenging activities of wild bitter melon (Momordica charantia Linn. var. abbreviata Ser.) in Taiwan. LWT-Food Sci Technol, 41, 323-330

34. Chung HS, Kim IH, Kim SH, Lee JH (2013) Antioxidant properties of Pinus koraiensis needle powder extracts as influenced by drying methods. Food Eng Prog, 17, 396-400

35. Kim JA, Lee JM (2004) The change of biologically functional compounds and antioxidant activities in Hizikia fusiformis with drying methods. J Korean Soc Food Cult, 19, 200-208
36. Re R, Pellegrini N, Proteggente A, Pannala A, Yang M, Rice-Evans C (1999) Antioxidant activity applying an improved ABTS radical cation decolorization assay. Free Radic Biol Med, 26, 1231-1237

37. Miller NJ, Rice-Evans CA (1997) Factors influencing the antioxidant activity determined by the $\mathrm{ABTS}^{+}$radical cation assay. Free Radical Res, 26, 195-199

38. Goycoolea FM, Cardenas A (2003) Pectins from Opuntia spp.: a short review. J Prof Assoc Cactus, 5, 17-29

39. Sa YJ, Kim JS, Kim MO, Jeong HJ, Yu CY, Park DS, Kim MJ (2010) Comparative study of electron donating ability, reducing power, antimicrobial activity and inhibition of a-glucosidase by Sorghum bicolor extracts. Korean J Food Sci Technol, 42, 598-604

40. Youn KS, Kim JW (2012) Antioxidant and angiotensin converting enzyme I inhibitory activities of extracts from mulberry (Cudrania tricuspidata) fruit subjected to different drying methods. J Korean Soc Food Sci Nutr, $41,1388-1394$ 